\title{
Deteksi Plasmodium falciparum dengan menggunakan metode real-time polymerase chain reaction di daerah Likupang dan Bitung
}

\author{
${ }^{1}$ David C. Tooy \\ 2 Janno B. Bernadus \\ ${ }^{2}$ Angle Sorisi \\ ${ }^{1}$ Kandidat Skripsi Fakultas Kedokteran Universitas Sam Ratulangi Manado \\ ${ }^{2}$ Bagian Parasitologi Klinik Fakultas Kedokteran Universitas Sam Ratulangi Manado \\ Email: davidtooy@gmail.com
}

\begin{abstract}
Malaria is one of the most important parasitic disease which is caused by Plasmodium spp. There are approximately 1,2 billion people in the world with high risk of getting malaria. Plasmodium falciparum ( $P$. falciparum) is the cause of tropical malaria or falciparum malaria, and is responsible for most of the mortality rate. Currently, real-time polymerase chain reaction (RT-PCR) is being studied as an alterative of conventional malarian examination. Mangold et al reported that RT-PCR have 94.1\% sensitivity and $100 \%$ specificity compared to microscopic examination in detecting $P$. falciparum. The aim of this research is to detect the presence of $P$. falciparum using RT-PCR in Likupang and Bitung region. This research were using descriptive design to find out the capability of real-time PCR method to detect $P$. falciparum in Likupang dan Bitung region. The researcher have examined 71 samples which are fulfill the research sample's criteria. Postive results of P. falciparum found in 18 samples (25,3\%) and negative results in 53 samples (74,6\%) of total 71 samples with using RT-PCR. No positive results were found in samples from Likupang. There are positive result of P. falciparum in samples from Bitung. It is concluded that RT-PCR method can detect the presence of $P$. falciparum from the samples obtained from Likupang and Bitung based on the presence of its DNA. This detection efford is done by using 18S rRNA as target gene and ajust specific temperature on the RT-PCR instrument.
\end{abstract}

Keywords: Plasmodium falciparum, Real-time Polymerase Chain Reaction (PCR), Detection

\begin{abstract}
Abstrak: Malaria merupakan salah satu penyakit penting yang disebabkan oleh parasit Plasmodium spp. Kira-kira 1,2 miliar penduduk dunia memiliki risiko tinggi untuk mendapat malaria. Di Indonesia sendiri, terdapat 343.527 kasus terkonfirmasi dan 45 kematian karena malaria. Plasmodium falciparum ( $P$. Falciparum) merupakan penyebab dari malaria tropika atau malaria falsiparum, dan bertanggung jawab atas sebagian besar angka mortalitas. Saat ini Real-Time Polymerase Chain Reaction (RT-PCR) telah banyak diteliti sebagai alternatif dari pemeriksaan malaria. Mangold dkk melaporkan bahwa real-time PCR memiliki nilai sensitivitas $94,1 \%$ dan nilai spesifisitas $100 \%$ terhadap pemeriksaan mikroskopis dalam mendeteksi $P$. falciparum. Penelitian bertujuan untuk mendeteksi $P$. falciparum dengan menggunakan RT-PCR di daerah Likupang dan Bitung. Penelitian ini menggunakan rancangan penelitian deskriptif untuk mengetahui kemampuan metode real-time PCR dalam mendeteksi $P$. falciparum di daerah Likupang dan Bitung. Tujuan penelitian ini ialah untuk mendeteksi keberadaan P. falciparum dengan menggunakan metode real-time PCR di daerah Likupang dan Bitung. Peneliti memeriksa 71 sampel darah yang memenuhi kriteria sampel penelitian. Hasil positif $P$. falciparum ditemukan pada 18 sampel (25,3 \%) dan hasil negatif pada 53 sampel (74,6 \%) dari total 71 sampel dengan menggunakan RT-PCR. Tidak ditemukannya hasil positif $P$. falciparum pada sampel dari Likupang. Ditemukan hasil positif $P$. falciparum pada sampel dari Bitung. Simpulan: Metode RT-PCR dapat mendeteksi $P$. falciparum berdasarkan keberadaan DNA-nya pada sampel yang diperoleh dari daerah Likupang dan Bitung. Deteksi ini berhasil dilakukan dengan menggunakan 18S rRNA sebagai gen target dan pengaturan suhu tertentu pada instrument RT-PCR.
\end{abstract}

Kata kunci: P. falciparum, Real-time Polymerase Chain Reaction (PCR), Detection

Malaria merupakan salah satu penyakit penting yang disebabkan oleh parasit Plasmodium spp. ${ }^{1}$ Kira-kira 1,2 miliar penduduk dunia memiliki risiko tinggi untuk mendapat malaria. Pada tahun 2013 World Health Organization

(WHO) 
memperkirakan ada sekitar 198 juta kasus malaria dan 584.000 kematian di seluruh dunia. Di Indonesia terdapat 343.527 kasus terkonfirmasi dan 45 kematian oleh karena malaria. ${ }^{2}$ Menurut Riset Kesehatan Dasar, ${ }^{3}$ insiden malaria pada penduduk Indonesia tahun 2013 adalah 1,9\%. Di Sulawesi Utara sendiri insiden malaria adalah sebesar 2,7\% dengan prevalensi $10 \%$. Insiden malaria di kabupaten Minahasa Utara adalah sebesar 2,3\% dan prevalensinya adalah sebesar 10,1\%. Di kota Bitung insiden malaria sebesar $1,6 \%$ dan prevalensinya sebesar 6,1\%. ${ }^{4}$

Plasmodium falciparum ( $P$. falciparum) merupakan penyebab dari malaria tropika atau malaria falsiparum, dan bertanggung jawab atas sebagian besar angka mortalitas. Malaria falsiparum memiliki perkembangan manifestasi klinis yang cepat dan menghasilkan parasitemia tinggi yang menyerang semua bentuk eritrosit. Infeksi $P$. falciparum dapat dikelirukan sebagai influenza, hepatitis, meningitis ataupun ensefalitis. $P$. falciparum juga dapat dikelirukan sebagai plasmodium lainnya misalnya Plasmodium vivax ( $P$. vivax) pada kasus infeksi campuran, atau Plasmodium knowlesi (P. knowlesi) yang memiliki manifestai klinis menyerupai $P$. falciparum. $^{5}$

Pengobatan malaria tidak dapat diberikan tanpa kepastian ditemukannya parasit malaria, baik secara mikroskopis maupun dengan pemeriksaan rapid diagnostic test (RDT). Oleh karena itu, keakuratan dalam diagnosis sangat penting dalam memerangi malaria. Disamping itu, pengobatan dengan dasar diagnosis yang tepat dapat mencegah terjadinya malaria berat dan resistensi obat yang memperberat upaya pemberantasan malaria.,6

Sampai saat ini pemeriksaan mikroskopis sediaan darah tebal dan tipis dengan pewarnaan Giemsa masih merupakan baku emas dalam menegakkan diagnosis malaria. Pemeriksaan mikroskopis dengan pewarnaan Giemsa dinilai sebagai instrumen diagnostik malaria paling efektif dan efisien oleh karena biayanya terjangkau, mampu mendiferensiasi spesies-spesies Plasmodium dan mengkuantifikasikan parasit dalam darah.

Polymerase chain reaction (PCR) merupakan salah satu metode biomolekuler yang telah dikembangkan untuk mendeteksi penyakit infeksi seperti malaria. ${ }^{8}$ PCR bekerja dengan mempernyak suatu sekuens gen yang diinginkan dan kemudian dibaca pada agarose gel yang telah dielektroforesis. Pada real-time PCR perbanyakan DNA dipantau secara langsung dengan teknologi cahaya optik, sehingga kuantifikasi menjadi lebih mudah. ${ }^{9}$ Saat ini real-time PCR telah banyak diteliti sebagai alternatif dari pemeriksaan malaria konvensional seperti pemeriksaan mikroskopis atau RDT. Studi oleh Mangold $\mathrm{dkk}^{10}$ menunjukan bahwa real-time PCR memiliki nilai sensitivitas $94,1 \%$ dan nilai spesifisitas $100 \%$ terhadap pemeriksaan mikroskopis dalam mendeteksi $P$. falciparum. Pada studi lain, Alam dkk ${ }^{11}$ menemukan nilai sensitivitas $97,1 \%$ dan nilai spesifisitas 97,6\% dalam mendeteksi $P$. falciparum. Real-time PCR juga dilaporkan dapat mendeteksi jumlah parasit sampai 0,17 parasit per $5 \mu \mathrm{l}$ darah pada seorang pasien yang tengah dalam pengobatan dari hari pertama sampai hari ke-lima.

Real-time PCR telah dilaporkan memiliki tingkat sensitivitas dan akurasi yang tinggi dalam mendeteksi $P$. falciparum. Oleh karena itu, peneliti tertarik untuk mendeteksi $P$. falciparum dengan menggunakan real-time PCR di daerah Likupang dan Bitung.

\section{PLASMODIUM FALCIPARUM}

\section{Karakteristik}

Parasit penyebab malaria termasuk dalam genus Plasmodium dan terdapat lima spesies yang menginfeksi manusia: $P$. falciparum, P. vivax, P. ovale, P. malariae dan $P$. knowlesi. Dari antara ke-lima spesies tersebut, $P$. falciparum merupakan jenis yang berbahaya karena dapat penyakit yang ditimbulkan dapat menjadi berat. $P$. falciparum dapat menyebabkan parasitemia tinggi dan menyerang semua bentuk 
eritrosit. Karakteristik $P$. falciparum dapat dilihat pada tabel 1.

\begin{tabular}{ll} 
Tabel 1. Karakteristik $P$. falciparuh \\
\hline Daur praeritrosit & 5,5 hari \\
Hipnozoit & - \\
Jumlah morozoit & 40.000 \\
hati & \\
Skizon hati & 60 mikron \\
Daur eritrosit & 48 jam \\
$\begin{array}{l}\text { Eritrosit yang } \\
\text { dihinggapi }\end{array}$ & Muda dan \\
Pembesaran \\
eritrosit \\
$\begin{array}{l}\text { Titik-titik } \\
\text { eritrosit }\end{array}$ & - \\
$\begin{array}{l}\text { Pigmen } \\
\text { Jumlah merozoit } \\
\text { eritrosit }\end{array}$ & Maurer \\
$\begin{array}{l}\text { Daur dalam } \\
\text { nyamuk pada }\end{array}$ & 10 hari \\
$27^{\circ} \mathrm{C}$ &
\end{tabular}

\section{Siklus hidup dan morfologi}

Salah satu hal yang membedakan antara $P$. falciparum dengan plasmodium lainnya adalah siklus hidupnya. Siklus hidup plasmodium yang menyerang manusia terdiri atas fase seksual eksogen (sporogoni) dalam badan nyamuk Anopheles dan fase aseksual (skizogoni) dalam badan hospes vertebrata. Fase aseksual terbagi atas dua daur, yaitu:1) daur eritrosit dalam darah (skizogoni eritrosit) dan 2) daur dalam sel parenkim hati (skozogoni eksoeritrosit), atau disebut juga dengan stadium jaringan. $P$. falciparum hanya memiliki satu generasi aseksual di dalam hati, dan setelah itu siklus dalam hati tidak dilanjutkan lagi. Perbedaan penting lain adalah bahwa $P$. falciparum dapat memodifikasi permukaan eritrosit memodifikasi perukaan eritrosit yang terinfeksi sehingga stadium akseksual dan gametosit dapat melekat di permukaan endotel organ dalam dan plasenta. Perbedaan morfologi $P$. falciparum bervariasi dalam setiap stadium parasit. Pada stadium dini, skizon $P$. falciparum dalam hati berukuran \pm 30 mikron. Parasit tidak memiliki bentuk hipnozoit dalam hati seperti $P$. vivax ataupun $P$. malarie, sehingga tidak menimbulkan relaps. $P$. falciparum mampu menghasilkan 40.000 merozoit dalam skizon hati yang siap menginvasi eritrosit. ${ }^{12}$

Dalam eritrosit pada stadium trofozoit muda, $P$. falciparum memiliki bentuk cincin yang sangat kecil dan halus dengan ukuran kira-kira seperenam diameter eritrosit. Dapat diamati dua butir kromatin pada bentuk cincin. Bentuk marginal dan accóle dapat ditemukan. kemudian bentuk cincin membesar hingga berukuran seperempat dan kadang-kadang setengah dari diameter eritrosit. Setelah 24 jam bentuk cincin dan trofozoit tua menghilang dari darah tepi karena tertahan dalam kaliper alat dalam sepert otak, jantung, plasenta, usus atau sumsum tulang untuk kemudian berkembang lebih lanjut. ${ }^{12}$

\section{Manifestasi Klinis}

Gejala-gejala awal atau disebut juga gejala prodormal, tidak begitu spesifik, yaitu sakit kepala, lesu, malaise, perut tidak enak, anoreksia, diare ringan, nyeri tulang dan otot. Gejala-gejala prodormal kemudian diikuti oleh gejala klasik malaria, atau biasa disebut dengan trias malaria yang terdiri atas tiga periode:

1. Periode dingin: Pada periode ini pasien mulai merasakan kedinginan hebat diikuti dengan menggigil seluruh tubuh, gigi gemeretak, kulit dingin, kering, pucat dan sianosis. Pasien berusaha membungkus diri dengan selimut. Periode ini berlangsung selama 15 menit sampai satu jam.

2. Periode panas: Pada periode ini suhu tubuh meningkat sampai $40^{\circ} \mathrm{C}$ atau lebih, kulit panas dan kering, dan muka memerah. Periode ini berlangsung selama dua jam bahkan bisa mencapai enam jam.

3. Periode berkeringat: Pada periode ini pasien mulai berkeringat, mulai dari 
temporal diikuti seluruh tubuh. Suhu tubuh menurun dengan cepat dan penderita merasa tubuhnya sehat kembali. Periode ini berlangsung 2-3 jam.

Secara keseluruhan, trias ini berlangsung selama 6-10 jam. Pada $P$. falciparum demam bersifat iregular, muncul setiap 24 dan sering dengan temperatur $40^{\circ} \mathrm{C}$. Anemia sering ditemukan pada penderita dengan malaria falsiparum, mulai dari derajat ringan sampai berat. Sering dijumpai pembesaran limpa atau splenomegali pada penderita malaria, limpa menjadi bengkak, nyeri dan terlihat. Masa inkubasi $P$. falciparum berlangsung selama 9-14 hari dangan periode prepaten yaitu 11 hari. $P$. falciparum dapat menghasilkan parasitemia yang banyak dan sering terjadi komplikasi. ${ }^{5,13}$

\section{REAL-TIME POLYMERASE CHAIN REACTION \\ Polymerase Chain Reaction}

Metode PCR merupakan suatu metode biomolekuler yang digunakan untuk memperbanyak sebuah sekuens DNA spesifik hingga terbentuk ribuan bahkan jutaan salinan. Hal ini dapat dicapai dengan menggunakan suatu enzim yang disebut polimerase. Proses pelipatgandaan ini dicapai dalam tiga tahap: denaturation, annealing (peleburan/penempelan), dan elongation atau extension (pemanjangan). ${ }^{9,14,15}$ Ketiga tahap ini membentuk satu siklus amplifikasi (Gambar $1)$.

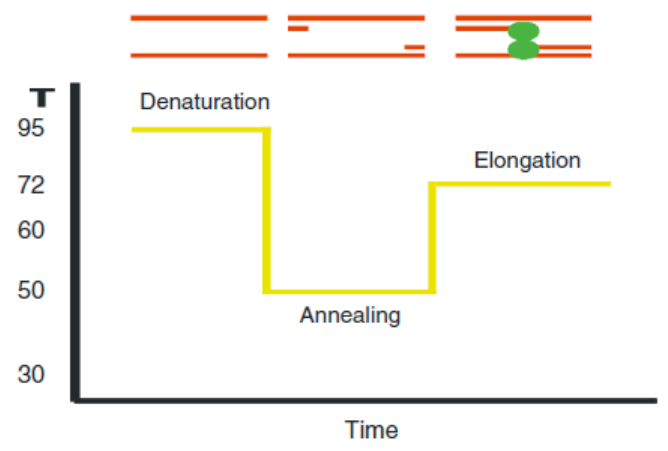

Gambar 1. Siklus amplifikasi DNA. ${ }^{9}$

\section{Prinsip kerja real-time PCR}

Real-time PCR merupakan sebuah modifikasi terbaru dari metode PCR konvensional. Prinsip kerjanya hampir sama dengan PCR konvensional, namun real-time PCR dapat mengkuatifikasi dan memonitor secara langsung amplifikasi dari suatu DNA spesifik. ${ }^{9}$ Amplifikasi DNA dapat dipantau oleh instrumen real-time PCR oleh karena adanya suatu zat yang dinamakan flourescent reporter. Flourescent reporter merupakan zat yang berikatan dengan DNA target dan memancarkan sinyal flourosensi yang menggambarkan jumlah produk yang dihasilkan. Flourescent reporter terdiri atas flourescent dye dan probe. Flourescent dye pada dasarnya zat yang berflourosensi ketika berikatan dengan DNA, sedangkan probe merupakan primer yang telah dilabeli dengan zat radioaktif dan bekerja seperti flourescent dye. Flourescent dye akan terus berikatan selama amplifikasi DNA, sehingga flourosensinya akan terus bertambah. Namun flourosensi akan berkurang ketika dye tidak mengimbangi jumlah DNA yang terus bertambah. Sinyal flourosensi ini ditampilkan sebagai kurva response yang menggambarkan jumlah DNA yang diperbanyak seiring jalanya siklus. ${ }^{9,16}$ Saat ini SYBR Green merupakan flourescent dye yang paling banyak digunakan pada real-time PCR (Gambar 2).

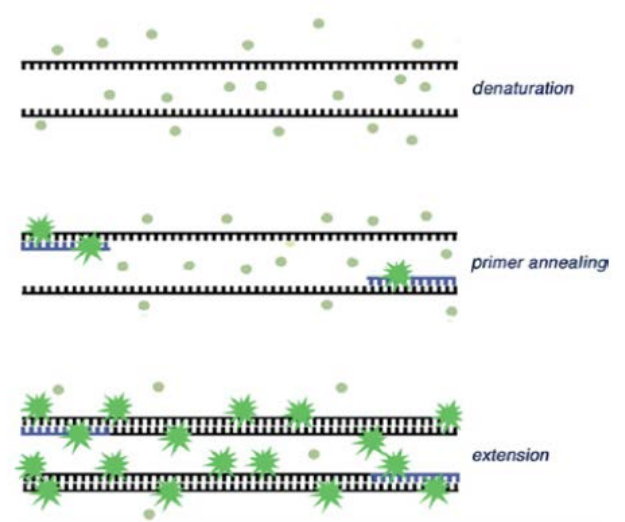

Gambar 2. SYBR Green selama amplifikasi PCR. Flourosensi dari dye ini akan meningkat 100-200 kali ketika berikatan dengan DNA. ${ }^{16}$ 
Pada siklus-siklus awal sinyal flourosensi masih lemah. Kemudian sinyal tersebut mulai meningkat secara eksponensial, menggambarkan DNA target yang berlipat ganda. Fase ini disebut sebagai fase perkembangan eksponensial atau exponential growth phase. Kemudian sinyal tersaturasi dan digambarkan sebagai kurva datar yang disebut dengan plateau phase (Gambar 3). Hal ini terjadi oleh karena reaksi mulai kehilangan kompenenkomponen pentingnya seperti primer, flourescent reporter atau dNTP. ${ }^{9}$

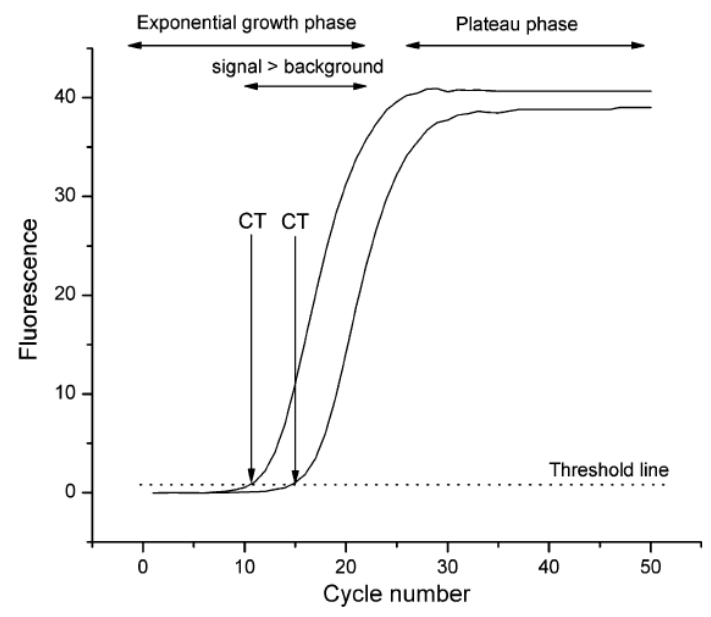

Gambar 3. Kurva Response. ${ }^{9}$

Dalam analisis ditentukan suatu ambang batas atau threshold untuk dapat mengetahui apakah flourosensi suatu sampel dihasilkan oleh amplifikasi DNA target atau tidak. Threshold dapat ditentukan langsung oleh alogaritme software real-time PCR yang tersedia atau dapat ditentukan secara manual. Ketika suatu sample DNA template diamplifikasi kurva response akan naik secara eksponensial hingga melewati threshold yang telah ditentukan. Sampel dengan kurva response melewati threshold dapat disebut positif memiliki target DNA yang diinginkan. Sementara itu, jika sampel tidak melewati ambang batas maka sampel dikatakan negatif. Analisis kurva melting dibutuhkan untuk memastikan spesifisitas dari amplifikasi real-time PCR. Jumlah siklus yang dibutuhkan untuk mencapai threshold disebut dengan nilai cycle threshold (CT). ${ }^{9,16}$

\section{Primer}

Ribosom merupakan nukleoprotein yang berfungsi untuk membentuk protein dari cetakan messenger RNA. Ribosom terdiri dari subunit besar dan subunit kecil. Subunit besar yang berfungksi untuk mengatur pebentukan ikatan peptida. subunit kecil yang berfungsi untuk membaca kodon messenger RNA dan sehingga dapat terjadi translasi untuk membentuk suatu protein spesifik. ${ }^{17}$ Parasit plasmodium mempunyai subunit kecil seperti 18S, 5.8S, dan 28S yang tidak sama dengan eukariota lainnya. ${ }^{18}$ Meskipun terdapat terdapat gen target lain seperti gen merozoit surface protein $^{17}$ dan gen mitokondra, gen var dan stevor ${ }^{19}$, kebanyakan primer real-time PCR menggunakan 18S rRNA sebagai gen target plasmodium spp. ${ }^{8,10,11,17,19,20,21}$ Dalam penelitian ini primer yang digunakan adalah PL1473F18 sebagai forward primer dan PL1679R18 sebagai reverse primer. Primer ini telah digunakan oleh Mangold $\mathrm{dkk}^{10}$ dan berhasil mendeteksi keberadaan $P$. falciparum.

\section{METODE PENELITIAN}

Penelitian ini menggunakan rancangan penelitian deskriptif untuk mengetahui kemampuan metode real-time PCR dalam mendeteksi $P$. falciparum di daerah Likupang dan Bitung. Penelitian dilaksanakan pada bulan November 2015 sampai Januari 2016. Sampel berupa darah EDTA yang diambil dari desa-desa di Likupang dan Rumah Sakit Budi Mulia Bitung. Pemeriksaan real-time PCR dilakukan di Laboratorium Parasitologi Klinik Fakultas Kedokteran Universitas Sam Ratulangi Manado. Peneliti mengekstrak DNA dari sampel darah dengan menggunakan Genomic DNA Mini Kit Genaid $^{\circledR}$. Hasil ekstraksi diambil $3 \mu \mathrm{l}$ tersebut kemudian kemudian dicampur dengan distilated water $(11 \mu \mathrm{l})$, master mix $(10 \mu \mathrm{l})$, forward primer $(0,5 \mu \mathrm{l})$, dan reverse 
primer $(0,5 \mu \mathrm{l})$. Campuran tersebut diperiksa dengan instrumen real-time PCR, TOptical Thermal Cycler 96 Biometra $^{\circledR}$. Denaturasi inisial $95^{\circ} \mathrm{C}$ selama 10 menit, diikuti siklus PCR 40 kali: $95^{\circ} \mathrm{C}$ selama 10 detik (denaturation), $50^{\circ} \mathrm{C}$ selama 5 detik (annealing), $\quad 72^{\circ} \mathrm{C}$ selama 20 detik (elongation). Melting programme dengan suhu $95^{\circ} \mathrm{C}$ selama 2 menit, $68^{\circ} \mathrm{C}$ selama 2 menit, dan Melting time selama 5 detik. Hasil PCR kemudian dibaca dengan menggunakan qPCRsoft 2.1.

\section{HASIL PENELITIAN}

Peneliti berhasil mendapatkan 73 sampel darah EDTA dalam jumlah volume yang bervariasi. Dari 73 sampel darah hanya 71 sampel yang diperiksa dengan real-time PCR oleh karena dua sampel tidak memenuhi syarat volume yang dibutuhkan untuk pemeriksaan.

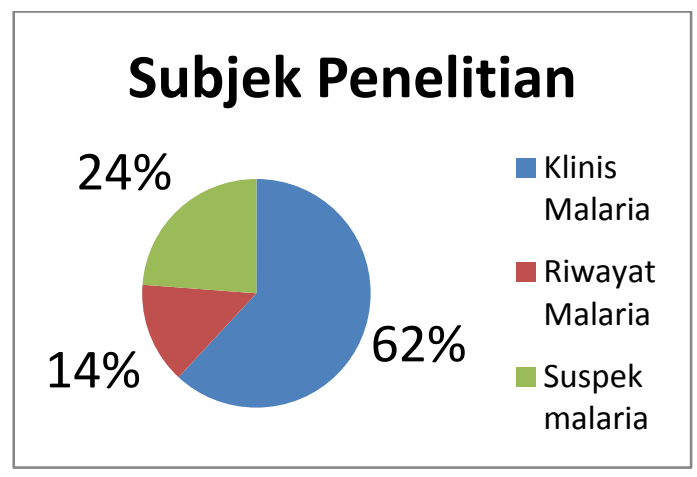

Gambar 1. Distribusi subjek yang dikelompokkan berdasarkan kriteria inklusi

Tabel 1. Distribusi responden berdasarkan jenis kelamin. Tabel 4. Distribusi frekuensi hasil pemeriksaan real-time PCR di Likupang dan Bitung.

\begin{tabular}{ccc}
\hline Real-time PCR & $\mathrm{N}$ & $\%$ \\
\hline Positif & 18 & $25,4 \%$ \\
\hline Negatif & 53 & $74,6 \%$ \\
\hline Total & 71 & $100 \%$ \\
\hline
\end{tabular}

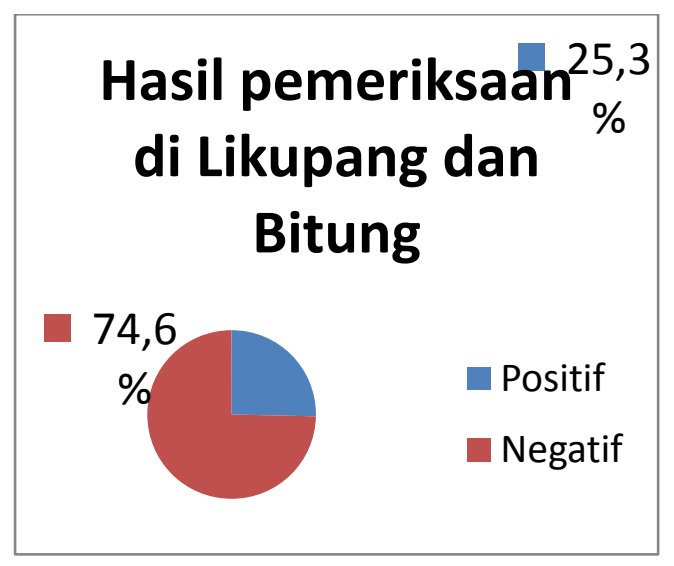

Gambar 2. Distribusi frekuensi subjek berdasarkan hasil pemeriksaan real-time PCR.

Tabel 2. Distribusi frekuensi hasil pemeriksaan real-time PCR di Likupang.

\begin{tabular}{ccc}
\hline Real-time PCR & $\mathrm{N}$ & $\%$ \\
\hline Positif & 0 & 0 \\
\hline Negatif & 36 & $100 \%$ \\
\hline Total & 36 &
\end{tabular}

Pada Gambar 3 dapat dilihat bahwa hasil positif $P$. falciparum hanya ditemukan pada 18 sampel yang memiliki gejala klnis malaria dengan menggunakan real-time PCR. Hasil negatif didapatkan pada 21 sampel lainnya yang memiliki gejala malaria. Hasil negatif juga didapatkan pada semua sampel dengan riwayat malaria (sembilan sampel) dan asimptomatik (15 sampel).

Tabel 3. Distribusi frekuensi hasil pemeriksaan real-time PCR di Bitung

\begin{tabular}{ccc}
\hline Real-time PCR & $\mathrm{N}$ & $\%$ \\
\hline Positif & 18 & $51,4 \%$ \\
\hline Negatif & 17 & $48,6 \%$ \\
\hline Total & 35 & $100 \%$ \\
\hline
\end{tabular}




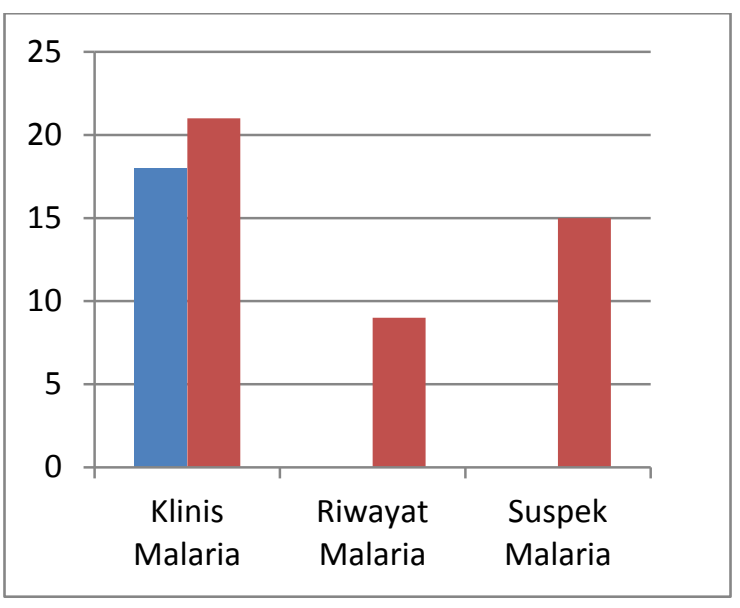

Gambar 3. Hasil real-time PCR berdasarkan kriteria inklusi

\section{BAHASAN}

Banyak studi yang telah menunjukkan sensitivitas dari berbagai metode PCR, baik konvensional maupun real-time, melebihi $90 \%$ terhadap pemeriksaan mikroskopis dalam mendeteksi adanya $P$. falciparum. ${ }^{7,8,10,11,17,19-21}$ Realtime PCR kemudian mulai banyak digunakan untuk mengevaluasi adanya parasitemia rendah. Telah dilaporkan bahwa real-time PCR dapat mendeteksi adanya parasitemia rendah pada 16 sampel dari 79 pasien asimptomatik, dimana pemeriksaan mikroskopis hanya dapat mendeteksinya pada enam sampel. ${ }^{22}$ Realtime PCR kemudian dipertimbangkan sebagai metode yang mungkin diterapkan untuk mendeteksi parasit pada karier asimptomatik.

Dalam studi ini, peneliti mencoba mendeteksi adanya $P$. falciparum di Likupang dan Bitung, dimana daerah tersebut masih dilaporkan adanya kasus malaria falsiparum. ${ }^{4}$ Melalui anamnesis singkat dan data sekunder yang diperoleh, peneliti membagi subjek kedalam kelompok yang memiliki gejala klinis malaria, riwayat malaria dan individu-individu asimptomatik yang tinggal serumah atau dekat dengan penderita malaria. Pada penelitian ini, peneliti hanya menemukan hasil positif pada subjek dengan gejala klinis malaria dan tidak pada subjek asimptomatik atau dengan riwayat malaria. Meski menurut penelitian sebelumnya real-time PCR dapat mendeteksi adanya $P$. falciparum pada pasien asimptomatik, hal ini belum dapat dibuktikan pada penelitian ini.

Seluruh subjek yang berada di Likupang dinyatakan negatif terhadap adanya $P$. falciparum dengan pemeriksaan real-time PCR. Walaupun perlu skrining yang lebih luas, hal ini mengindikasikan bahwa endemisitas daerah Likupang terhadap $P$. falciparum mulai menurun, dan tindakan pengobatan dan pencegahan yang dilakukan oleh tenaga kesehatan setempat telah membuahkan hasil.

Sementara itu, dari 35 subjek dari kota Bitung, 18 sampel positif mengandung DNA $P$. falciparum. Seluruh sampel dari Bitung merupakan subjek dengan gejala klinis malaria. Skrining lebih lanjut diperlukan untuk memastikan tingkat endemisitasnya.

Saat melakukan analisis, peneliti menemukan beberapa sampel negatif yang memiliki nilai CT yang rendah. Hasil ini dapat dikelirukan sebagai hasil positif (lihat di lampiran). Perlu dilakukan analisis kurva amplifikasi dan kurva melting untuk dapat memastikan hasil tersebut. Untuk melakukan analisis tersebut dan mendeteksi keberadaan parasit, pengalaman dan pengetahuan memadai tentang real-time PCR, malaria dan aspek biomolekulernya sangat dibutuhkan pemeriksa.

Para ahli belum mencapai kesepakatan bersama tentang assay (primer) dan metode yang dipilih dalam deteksi malaria. ${ }^{19}$ Peneliti menggunakan primer dengan target gen yang umum digunakan pada real-time PCR, yaitu 18S rRNA dengan sekuens gen yang sama yang digunakan oleh Mangold dkk. ${ }^{10}$ Peneliti juga menggunakan pengaturan suhu dan jumlah siklus yang sama dengan yang digunakan Mangold dkk. ${ }^{10}$ Didapatkan optimalisasi yang baik dengan menggunakan primer tesebut pada instrument yang digunakan peneliti, TOptical Thermal Cycler 96 Biometra $^{\circledR}$. Peneliti mendapat hasil yang dapat diandalkan dengan menggunakan primer 
dan pengaturan suhu ini untuk mendeteksi DNA parasit. Hingga terdapat suatu konsensus tentang assay apa yang harus digunakan, peneliti menimbang assay ini dapat digunakan dalam mendeteksi $P$. falciparum.

Kekurangan dalam penelitian adalah bahwa peneliti menyatakan hasil postif berdasarkan keberadaan DNA P. falciparum pada subjek. Meskipun keberadaan DNA mengindikasikan adanya infeksi $P$. falciparum, dibutuhkan studi lebih lanjut untuk membandingkan hasil yang didapatkan dengan menggunakan pemeriksaan baku emas atau pemeriksaan lainnya. Selain itu, daerah yang menjadi tempat penelitian mencakup wilayah yang luas, dan dengan sampel yang ada tingkat endemisitas malaria falsiparum saat ini masih belum dapat diukur.

\section{SIMPULAN}

Metode real-time PCR dapat mendeteksi $P$. falciparum berdasarkan keberadaan DNA-nya pada sampel yang diperoleh dari daerah Likupang dan Bitung. Deteksi ini berhasil dilakukan dengan menggunakan 18S rRNA sebagai gen target dan pengaturan suhu tertentu pada instrument real-time PCR. Tidak ditemukannya $P$. falciparum pada sampel dari daerah Likupang. Peneliti menemukan $P$. falciparum pada beberapa sampel dari daerah Bitung.

\section{DAFTAR PUSTAKA}

1. White NJ, Pukrittayakamee S, Hien TT, Faiz MA, Mokuolu OA, Dondorp AM. Malaria. Lancet. 2014; 383: 723-35

2. World Health Organization. World Malaria Report. Geneva: WHO Press; 2014.

3. Depkes RI. Riset Kesehatan Dasar (RISKESDAS). Jakarta:Badan Penelitian dan Pengembangan Kesehatan;2013.

4. Sumiarti, Lestari W, Handayani S, Herman $S$ (ed.) Riset Kesehatan Dasar Dalam Angka Provinsi Sulawasi Utara. Jakarta: Lembaga Penerbitan Badan Litbangkes; 2013.

5. Harijanto PN,Nugroho A, Gunawan CA (eds.) Malaria dari moleculer ke klinis.Ed. 2. Jakarte: EGC; 2009.
6. Wongsrichanalai C, Barcus MJ, Muth S, Sutamihardja A, Wernsdorfer WH.A Review of Malaria Diagnostic Tools: Microscopy and Rapid Diagnostic Test (RDT).Am. J. Trop. Med. Hyg. 2007; 77: 119-27.

7. Johnston SP, Pieniazek NJ, Xayavong MV, Slemenda SB, Wilkins PP, da Silva AJ. PCR as a confirmatory technique for laboratory diagnosis of malaria.J. Clin. Microbiol. 2006;44(3);1087-9.

8. Lee M, Tan C, Aw L, Tang C, Singh M, Lee $S$, et al. Real-time flourescence-base PCR for detection of malaria parasites. J.Clin. Micriobiol. 2002; 40(11):4343-5.

9. Kubista M, Andrade JM, Bengtsson M, Forootan A, Jonak J, Lind K, et al. The real-time polymerase chain reaction. Molecular Aspects of Medicine. 2006; 27:95-125.

10. Mangold KA, Manson RU, Koay ESC, Stephens L, Regner M, Thomson RB, et al. J. Clin. Micriobiol. 2005;43(5):2435-40.

11.Alam MS, Mohon AN, Mustafa S, Khan WA, Islam N, Karim MJ, et al. Real-time PCR assay and rapid diagnostic tests for the diagnosis of clinically suspected malaria patients in Bangladesh. Malaria Journal. 2011;10(175):1-9.

12. Sutanto I, Ismid IS, Sjarifuddin PK, Sungkar S. Parasitologi kedokteran. Edisi ke-4. Jakarta: Balai Penerbit FK UI;2008.

13.Bartoloni A, Zammarchi L Clinical aspects of uncomplicated and severe malaria.Mediterr J Hematol Infect Dis. 2012;4(1).

14. Solanki G. Polymerase chain reaction. International Journal of Pharmacological Research. 2012;2(3):98-102.

15.Ninfa AJ, Ballou DP, Benore $M$. Fundamental laboratoryapproaches for biochemistry and biotechnology. $2^{\text {nd }}$ Ed. Hoboken, New Jersey: John Willey and Sons;2010.

16.Fraga D, Meulia T, Fenster S. Real-time PCR. In: Gallagher SR, Wiley EA (eds.) Current Protocols Essential Laboratory Techniques. Wily; 2008. p1-32.

17.Bernadus JBB. Diagnosis malaria pada sampel urin dengan teknik polymerase chain reaction. Tesis pascasarjana. Universitas Indonesia, Jakarta; 2006.

18.Gardner MJ, Hall N, Fung E, White O, Berriman M, Hyman RW, et al. Genome sequence of the human malaria parasite 
Plasmodium falciparum. Nature. 2002;419;498-511.

19.Alemayehu S, Feghali KC, Crowden J, Komisar J, Ockenhouse CF, Kamau E. Comparative evaluation of published realtime PCR assays for the detection of malaria following MIQE guidelines. Malaria Journal. 2013;12(277):1-8.

20.Matisz CE, Naidu P, Shokoples SE, Grice D, Krinke V, Brown SZ, et al. Post-arrival screening for malaria in asymptomatic refugees using real-time PCR. Am. J. Trop. Med. Hyg. 2011;84(1):161-5.
21.Gama BE, Silva-Pires FES, Lopes MNR, Cardoso MAB, Britto C, Torres KL. Realtime PCR versus conventional PCR for malaria parasite detection in low-grade parasitemia. Experimental Parasitology. 2007;116:427-32.

22.Voa KDV,Bigotc P, Gazina P, Sinoua V, Pinad JJ, Huynhb DC, et al. Evaluation of a real-time PCR assay for malaria diagnosis in patients from Vietnam and in returned travelers. The Royal Society of Tropical Medicine and Hygiene. 2007;101:422-8. 